\title{
Transport, Supply, and Equipment of the British section of the Commission for the Delimitation of the British and Portuguese Spheres of Influence in East Africa, 1892
}

\section{J. J. Leverson R.E.}

To cite this article: J. J. Leverson R.E. (1894) Transport, Supply, and Equipment of the British section of the Commission for the Delimitation of the British and Portuguese Spheres of Influence in East Africa, 1892, Royal United Services Institution. Journal, 38:192, 115-132, DOI: 10.1080/03071849409416978

To link to this article: http://dx.doi.org/10.1080/03071849409416978

曲 Published online: 11 Sep 2009.

Submit your article to this journal $₫$

ЏII Article views: 4

Q View related articles ¿ 


\section{OCCASIONAL PAPERS.}

TRANSPORT, SUPPIY, AND ERUIPIINNT OF THF BRITISI SECTION OF THE COMMISSION HOR THE DFLIMITATION OF THE BRITISH AND PORTUGUESE SPHERIS OF INFLUENCL IN EAS'T AFIRICA, 1892.

$$
\text { By Mrajor J. J. LEversox; R.E. }
$$

Tre line agrecd to by Great Britain and Portugal as the bonndary between their respectire spheres of influence in East Africa, south of the Zambesi, is laid down in general terms in Article II of the AugloPortaguese Conrention of the 11th June, 1891.

Starting from the Zambesi, near Zumbo, it rans due south till it meets latitude $16^{\circ} \mathrm{S}$., and then follows a westerly dircetion as far as the point where the River Mnzoc is intersected by longitude $33^{\circ} \mathrm{E}$. 'There it tarns sharply to the right, aud continues generally in a southerly direction to the River Sabi, ascends that river from the point where it strikes it to its junction with the Lundi, and then runs: about south.west in a straight line to the north-cast corner of the 'Transval, which is situated at the janction of the Rivers Unvubn and Limpopo.

T'o deternine accuratels, and mark out on the ground, as much of the above line as time wonld permit was the object of the operationsin the field of the Anglo-Portuguese Delimitation Commission in 1892. Both extrensities of the lino being situated in parts of the country very difficult of access, and the boundary in the neighlombood of Massi-Kessi being tho portion that pressed most for settlement, it was determined to make tlat place our headquarters. and the starting point of the surrey, and to work north and south from it.

The British section of the Commission consisted of myself as Coinmissioner, Captain S. C. N. Grant and Lient. C. S. Wilson, R.F., Captain F. E. Lawrence, Riflo I3rigade, Surgcon-Captain Rayner, Grenadier Guards, M[r. Saville (interpreter), and five non-commissioned officers of Royal Engincers (traincd surveyors). After oularrival in Manica wo were joined by the lato Captain E. C. Chamley Turner and sis troopers of the British South Africa Company's. police, bringing up the total number of whito men to be provided for including one servant, to 19 . The other scrvants consisted of a Capeboy, three Kulus from. Natal (two of whom deserted on the way up from the coast), three Indians, and a number of locally-engaged natives. 
Lerving Souibampton on the 19th March, 1892, in the ss. "Moor," of the Union Line, we transhipped at Natal into a coasting steamer, and reached Beira, the port from which we wero to proceed inland, on the 22nd April.

There our difliculties commenced, for the steamer on which we had been relying to tow barges containing onr bagga'ge and supplies up the Pungwe to Mapanda's, the higliest point to which tho river is navigable in the dry season, lind ventared farther up stream during the inundations, and had been left high and dry when the waters subsided.

No other steamers suitable for our purpose being arailnble, wo had to hare recourse to sailing-boats. It took several days to collect the seren which were found to bo necessary to carrs eversthing which was to be conseyed to Mapanda's. In addition to personal baggage zind camp equipment, we lind with us a large scientific outfit for the survey opcrations in connection with the delimitation, 286 cases (each case one min's load) of provisions, spirits, \&c. (calculated to bo sufficient to last 12 Europeans for from cight to nine months), a large number of bales of goods for baiter, and $400^{\circ}$ loads of rice. 'lhis rice was merely' a first instalment of what was required for the supply of the porters. It was subsequently largely augmented by a further consignment from 13oira, by parchases at Mrassi-Kussi and Umtali, and by barter with the natives liring along our line of march from Jiassi-Kessi to the Sabi River.

Having despatched the last of the sailing-bonts from Boira on the -2 Gth April, I followed next day with Captnin Grant in the eutter of H.M.S. "Racoon," towed by" a small stenm launch, by means of which $I$ hoped to be able to render assistance to any of the sailinghoats which might liave got stranded on the innumerablo and constantly shifting sand:banks in the rirer. On nuriral at Minpanda's, lowever, on the morning of the 2Sth, we found that all the boats had reaclied there without accident.

Owing to reports that native porters were vers diflicnlt to get in the country we were about to pass throngh, and also that those who vere obtainable rero nnreliable, the Portuguese Governinent hat lindly undertaken, at my request, to collect porters for our party in the Inhambane district. At Mapanda's 176 of these joined us. 'They were in partics varying in numbers from seven to about 35, each under an Induna or headman. Throughout the expedition, even when the Commission was split up into small sections, the porters were kept as far as possible under their own Indunas, who woro held responsible for them both on tho march and in camp.

In order to be able to identify the porters, each one was giren a small tin dise with a number stamped on it, which he usually wore attached to a coloured cord round his neck. The Indunas received larger dises, of which thej were rers proud.

Up till the lst May wo were engaged in uuloading the boats, drying some of the rice which had got wet during a storm on the journey up the river, sticking those stores wlich were to bo left temporarily behind at Mapanda's, and in weighing and arranging in loads suitable 
for carrier transport erergthing that we were to start with on our march up countrs.

Wo left Mapanda's on the afternoon of the lst May, our marchingout strength being 12 Furopeans, seven coloured serrants, $165^{\natural}$ porters, seven Indunas, and fire riding ponies. Of the loads, 40 consisted of rice for issue to the porters after the three dass' rations which each man at startirng carried for himsclf, in addition to his load, had been exhaustel. All loads were made up to weigh as nearlyas possible 50 lbs. each. As a matter of fact, tliey varich from aboui 4S libs. to 55 lbs.

The cooking-pots for the nntires were carried by the Indunas, wl:o dirl not, as a zule, carry any other londs.

On the erening of the 7th Mas we reached Minndigo's, nbont 9? miles from J/apanda's, the average daily march (taking the time occupied on the journey as $6 \frac{1}{2}$ day's) being 1.4 miles. 'This we found was ns much as we could get the porters to do; they were still new to the work, tho weather was hot, and the clense, tall grass, $6 \mathrm{ft}$. to $10 \mathrm{ft}$. high, through which we had to force our way nlong the greater part of the route impeded progress very considerabls.

Later on, when the men had become more accustomed to the loads, we were able to make some what longer dails marches, eren in the mountainous portions of the country, and on a fer occasions we did as much as 2l, and cren 22 wiles a day.

Tho Sth Mray was a day of rest. On the 9th, the whole of the porters, except some few who were footsore, set out unler Ciptain Lawrence to reciurn to Mapanda's, and bring up fresh loads. We had not been able to purchase any food for tho natives on the way up, and the 40 bags of rice with which we had started were mapidydiminishing. The daily ration for natives was $2 \mathrm{lbs}$. either of flour. or meal, and a littlo salt when there was any to be had. In addition to this, they were given meat whenever any game was shot or a sick ox killed, but, except when wo were able to distribute it in large quantities, meat was looked upon as an extra, and tho rice ration was not reduced. The supply of meat was vers irregular, and at times the men were two, and eren three, weeks without any. They were not particular as to its quality. or state when-served out to them, and ato the flesh of an ox which liad suffered from lung sickness or the bite of the tsetse fly with as much relish as if it had been that of a liealthy one. Whenerer they had a supembundance of meat, all thint was not requircd for immediate consnmption was mado into biltongHesh cut into long narrow strips and dried in the sun. The matires are fond of salt, but it is not looked upon as a necessars, and ther did not complain when they did not get any. Chili peppers, which were frequently found growing wild, wero a very farourite condiment, and used to be cooked with the rice. Water was the ordinary drink of the natives, though, whenever it was to bo had, thes used to get from the rillages pombi-2 kind of beer brewed from natire grain.

1 Including tro spare porters without loals. 
On the raiions issued to them our porters did really good work, nud throve well, all of them looking much healthier ani stronger at the end of the seven months they were with us than when they first joincd us. There was rery little sickness amongst them, and no death.

It was almost an invariable dule to make two marches every day. 'Their length was naturally somenhat dependent on the intervals between the places where drinking water was obtainable. The arerage rate of progress of the cararan when on the move did not at first excecd two miles an hour, including short halts. Later on, when wo had got the porters better in hand, and they had grown accustomed to carrying the loads, the averago was increased to nearly $2 \frac{1}{2}$ miles an hour, and sometimes even that was excceded.

The hour of starting in the morning varied slightly with the season of the year. In May we used to rise at dawn (about 5.45 4.M.), strike our camp, hare coffec, and be on the move about 40 minates after réveille had sounded. 'The mid-day halting place was reached uswally between 10 A.Y. and 11 A.3. We rested there till between $\mathrm{Z}$ and 2 P.M., and then marched till about 5 P.M.

In Jaly, in the mountainons districts of Manica, it was intensely cold (almost freczing) in the early morning, and the porters complained that the cold ground and grass stumps hurt their feet so much that wo often waited till the sun was well up (between 8 and 8.30 A.3r.) before starting. On these occasions the mid-day halt was: reduced to one and a-half or two hours. In September, October, and Norember, when the weather had again become liot, we nsed to rise in the dark, so as to be able to start the moment it was sufficiently light to see our way, and reach our resting place by 9 A.Y., as by that hour the rays of the sun had become excessively powerful. At this time of year, our departuro in the afternoon was generally delayed till about 3 1..Y., and we then marched till between 6 and 7 P.M.

On the 25th Mlay, Captain Lawrence and the porters who had returned with him to Mapanda's rejoined us at Shimora's, a point about. 22 miles bogond Mandigo's on the road to Mrassi-Kessi, to which, in their absence, we had mored with the assistance of an ox-ragon sent from Untali to meet ns.

Tho experience gained in the preceding year (1891) had been to the effect that Mandigo's was ontside tho tsetse fly zone, but it has since been ascertained that animals are not safe from its rarages till Slumojn's is reached on the journey up country. Everyone of the 12 oxen employed by the Cornmission between Mandigo's and Shimoga's died within thee weeks.

On starting from Mapanda's we had fire riding ponies with us, which wo had brought from Natal. Though they were all bathed every day with a so-called anti-tly solation, they begnn very soon to waste away, and within a very few weeks they all died, or became so emaciated and paralyzed that they.had to be shot.

From Shimoya's thero is a vagon road to Manica, made in tho enrly part of 1892 under the direction of $\mathrm{Mr}$. Selous, the well-known explorer and hunter. Making a wagon road in a newly opened-up dis- 
trict of $\Lambda$ frica consists merely in removing enough trees to allow a wagon to pass, corduroying swampy places, aud cutting down the binks of the streams at the drifts so as to form ramps not too steep for whecled traffic. Occasionalls, if the stream is decp and narrow, and the banks are stecp, a rough wooden bridgo is thrown across.

On the afternoon of the ?6th Mray we set out from Shimosa's to continuo our journey up conntry, our baggage nnd stores being carricd as follows:- $A$ bout 5,000 lbs. in a Cape buck-wagon, 3,000 lbs. in a tent-wagon, and 40 loads by porters.

The remainder of the porters, about 105 in number, 15 having deserted, were at the same time despatched to Mapanda's for further supplies. This time they were sent in charge of their orn Indanns, and were not accompanied by anj Europenns.

We did not reach Massi-Kessi till the end of the morning march on the 30th MIas, though tho distance from Shimoya's is only 41 miles, the arerage daily rate for the four days being onls 11 miles. This excecdingly slow rate of progress was due entirely to the diffcultics and delays in getting the wagons across some of the drifts at which the streams were crossed.

When Captain Isawrenco returned to MIapanda's from Mradigo's he had found a good many natires arriving at the former placo in search of employment, and, through their headmen, he had arranged for some of them to carry loads for us to Massi-Kessi. The usual agrecment was $3 l$. sterling, or, if gold were not available, goods to the value of about $1 l$. 1s. to $1 l$. 5s. from the traders' stores at $\mathrm{Mra}$ panda's, and rice for the jonrney up for cach load delivered at MIassiKessi. These porters insisted on prepajaent, but we found them nost trastworthy, and throughout the expedition we never lost a single load.

On the lst June we had already altogether about 450 loads at MIassiKessi. These were subsequently enpplemented by tho loads brought up by our own (Inhambane) porters on their third journey from Mhapanda's, and by loads brought up by further batelies of porters engaged localls by Messrs. Robbert \& Co., who had been appointed agents of the Commission at Mapanda's.

The total number of loads taken with us, or subsequently desyatched, from MIapanda's was as shown in the table on p. 120.

At Mrassi-Kessi I was able to enter into contracts with some traders for the supply of a considerable quantity of natirc meal for issuo to the porters in lieu of rice. In order to facilitate the transport arrangements, I was anxious that part of this should be delivered at rarious points on the route which the Commission was about to take on its journes south to tho Sabi, bat all the traders with one excepiion refused to deliver anywhere except at Massi-Kessi or. Untali, and the one who formed tho exception, who had agreed to furnish a large quantity at Chimanimani, about 70 miles south of Massi-Kessi, failed utterly to carry out his contract.

The amount of weal or rice required for the daily consumption of the Inhambane porters, guides, and other's attached to the Commission after our arrival at Massi-Kessi was about 7 loads.

roL. XXXYIIr. 


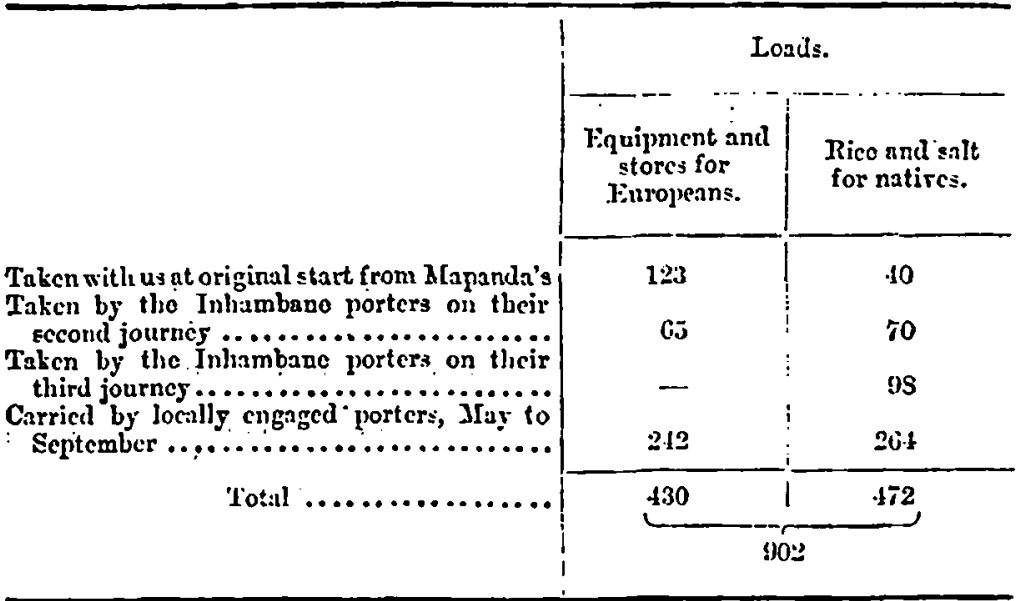

No reliable information being obtainable about the country sonth of Minssi-Kessi, I mato a recomnaissance in June, accompanied by Captain Lavience. On reaching the Chimaumani Pass, we heard thint the country further to the south was more thickly inholited, and it. was reporfer that a considerable quantity of meal could be obtained, though, it would probably take some time to collect. It wes, tlierefore, deciled that while I returned to Massi-Kessi, Captain Lawrence should remain behind with $\mathrm{a} \mathrm{far}$ of the porters, with instructions to establish a lepôt, and purchnse what meal, goats, and ponlty' he could, in exchange for barter groods.

On the route between Mapanda's and Massi-Kessi, the natires preferred to be paid in gold or silrer rupees, but those everaged in the less travelled regions further south liad no idea of the ralue of mones, and did not care for it, and would hardly ncecpt pazment excepit in goods. White cotton sheeting (limbo) is the staple article of barter, thonghi in some places coloured cottons were asked for. Blankets also are much prized, and beads and brass wire in small quantities. Fimpty solid-diawn cartridge cases, which the natires convert into siutf-boxes and wenr in their enrs, were at one time nseful, bit the maxket soon became overstocked with them. Salt.was grectily asked for everywhere, except along the Limpopo River, where theie are saline earths from which salt is extracted by rough processes. Gunpowder would have commanded $a$ very high price, but this we refused to sell.

The collcetion of meal at a depót was a somerhat tedious and slow affair. After establishing our camp, we used to send out to tho villages in the vicinity, to let the inbabitants know that wo were anxious to purchase meal, fe., and that everything they brought in. rotid be paid for at a fair valuc. It took some tinuc to prepare the meal, as grain is usaally stored in the natire granaries undergromu, snd the zncthod of grinding is not very rapid, the 
grain being first stamped in a wooden mortar, and then ground by hand between two stones. The meal when ready was invariably brought in by women in baskets or round dishes. They were gencrallyaccompanied by their husbands, bnt in some places as soon as they found that they liad nothing to fear from ns they used to come alone. Tho baskets of meal varied from $2 \mathrm{lbs}$. to $20 \mathrm{lbs}$, and as they belonged to different owners each had to bo brought separately.

Jieal purchased, but not required for consumption or issue to our porfers at the depôts, was inade up into loads suitable for transport. When cmpty rice sacks were not arailable, long cylindrical bags wero made out of the bark of trees.

I got back to Mrassi-Kessi on the 25th June, and immediately commenced to despatch parties of porters with supplies for delivery to Captain Lawrence at Chimanimani. For this purpose, in addition to the Inhambane porters, natives whom we were able to collect in the neighbourbood of Mrassi-Kessi were cmployed. The price paid to the latter wis 10s. pre load from Massi-Kessi to Chimanimani. In the first instance, two Europeans were sent in charge of each party of natives, but when the route became better known they went under their own Indunns. Ench head of a party was always given a was bill, showing the number of loads in his charge and their contents.

Hnving ascertained on the return -march to Mrassi-Kessi that it would be possible to collect a small quantity of meal at Setchagwa's, a point about midwny between Massi-Kessi and Chimanimani, a small trading station was established there in charge of two of the British Sonth Africa Company's police. This cnabled tho partics to deliver their loads intact at Chimanimani, and to leave the bulk of the meal collected there available for operations further to the south. 'The detril of the working of the system wns as follows :- M I Iassi-Kessi to Chimanimani was from 5 to $5 \frac{1}{2}$ days' march for porters with loads. On leaving Massi-Kessi each man took with him, in addition to his load, 3 days' supplies for himself. 'These were probably consumed by the time he reached Setchagwin's. At the latter place he was given a 3 days' further supply, which with about another 3 days' rations, issued at Chimnnimani, where one day was allowed for rest, brought him liack to Setchagwa's, when he was giren enough to carry him on to Massi-Kessi. The Indunas of parties of porters were always obliged to produce last mation ecrtificates before food was issued to them at any depôts.

During my absence Captain Grant aud Licutenant. Wilson had been engraged in survey operations in the neighbonrhood of MassiKessi. On the 1st July they started to contiuue their work to the south, taking with them two non-commissioned officers of Royal Engincers. They were nccompanicd by about 50 porters carrsing bngrga!e, equipment, and instruments, is well as about three weeks' rations for the Furnpeans of the party, and -10 days' rations for the natires. It was arranged that farther supplies for the natives were in tlic first instance to b3 obtained from the depôt at Setchagwa's, and that liter on supplies, both for natives and Enropeans, would be found K 2 
awaiting the party's arriral at Captain Iawence's camp at Chimanimani.

On the 2nd July I started on a week's reconnaissance to the north, accompanied by Captain Turner, Dr. Rayner, and some of the Portngueso officers belonging to the Commission, learing Mr. Saville (interpreter) at Mnssi-Kessi to superintend the further despatch of loads to Chimanimani.

On the 15th July, sufficient supplics for nenrly four months' consumption having been sent forward, I again left Massi-Kessi for the sonth with the headquarters of the Commission. During our absenco Corporal Lewis, R.E., remained behind in chargo of tho reserve stores of the Commission. We reached Captain Lawrence's camp at Chimanimani on the 20th, and on the 2 st were joined there by Captain Grant's party.

On the 23rd I proceeded further to the south with Captain Lawrenco and Mr. Saville, leaving Captain T'urner and Dr. Rayneltemporarily at Chimanimani, while Captain Grant and Licatenant Wilson continued their surves operations.

Having discovered on the right bank of the Lusitu lirer, abont 30 miles from Chimanimani, a site suitable for a depôt, situated in a district in which considerable supplies were obtainable, word was sent back to Captain Tumer to arrange to send on all stores to the Lusitu Rirer, and as soon as this was done to abandon tho depôt at Chimanimani.

Arrangements wore likewiso mado for shifting the depot at Sctchagwa's to Malanda's, a natire rillage almost cxactly midway between Massi-Kessi und the Isusitu.

As far us Malanda's wo were eventually able to make use of carts for bringing meal and rice from Mrassi-Kessi, a road for this purpose being made by the Portuguese and ourselves. After the road had been completed (end of July), ox-carts wero able to travel along it at the rate of 10 to 14 miles a day. Beyond Mnlanda's the country soon became so mountainous that it was necessary to gire up all idea of further emplnyment of wheeled trausport.

On the $26 t^{2}$. Juls, leaving Captain Lawrence to form the depôt on the Isusita. I started on a reconnaissance to the south-west, accompanird by Mr. Sarille. On the $30 \mathrm{th}$ we reached a group of kraais belonging to the Chicf Mapungane, where it was decided to form another derôt. Next day, learing Mr. Sarille to collect supplies there, I returned to the Lusitu by a more direct route, arriving there on the 2nd $\Lambda$ ugrust. On the 5th $I$ again left the Lusita, and reached Arapangane's again on the 8th.

Subsequently reconnaissances were mado to the south and southwest, and d'pôts were established on the Inyamgamba, 37 miles from Mapungane 8 , and on the right bank of the Sabi, a fer miles above its junction with the Lundi ( 50 miles from the Inyamgamba).

$B_{5}$ the 7th September the surrey operations had been carried down to the Sibi, and a considerable supply of food had been delirered there by cur porters. Before retracing our steps to Mrassi-Kessi, the line of frontier between the Sabi and the Lirnpopo still remained to 
be explored and mapped. The information we were able to obtain about the country between these rivers was of the scantiest; all that we could learn from the natires was that it was covered with thick bush, that water was extremely scarce, that the population was very sparse, and that wo should not be able to obtain ans supplies, tho prerious scason's harvest having failed altogether on account of a drought.

This was corroborated by Corporal Whittle, who returned to tho Sabi on the 6th September; having made a reconnaissance to tho IIahnnje River, about 46 miles to the soath-cast in the direction of our objectire point on the Limpopo.

In view of the probable difficultics with respect to supplies and water, it was decided to reduce tho party which was to proceed to the Limpopo, to its smallest possible dimensions, and to cut dorn the baggage and equipment of all kinds. It was erentually arranged that Captain Grant, Mr. Sarille, and one of the non-commissioned ofticer's of Royal Lingineers were to atcompany me; the rest of the Commission being left under the charge of Captain Lawrence, with instrnctions to finish up the survey rork, erect beacons, and gradually withdraw towards Massi. Kessi.

'The actual strength of the party which set out from the Snbi on the 10th September was as follows:-Myself, Captain Grant, MIr. Sarille, Corporal Johnson, R.E., and one Furopenn servant (5 whites), two coloured servants, two Indunas, and 60 porters.

The loads were made up as follows :-

For myself and Captain Grant (baggage, tents, bedding, instruments, despatch-boxes, and rifles) $\ldots \ldots \ldots \ldots \ldots \ldots \ldots \ldots \ldots \ldots \ldots \ldots \ldots \ldots$.

Mr. Saville, Corporal Johnson, and Furopean servaut (baggage, tents, and bedding) ..........

'Two coloured eervants (baggage and bedding)...

Cooking-pots, water-buckets, and lanterns.......

Ammunition...........................

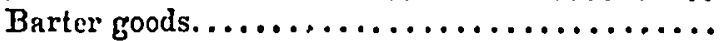

Groceries (29 dass) ....................

Spirits and medical comforts................

Tools ....................................

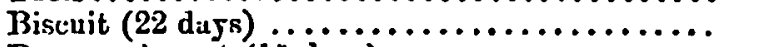

Preserved meit (10 dars) $\ldots \ldots \ldots \ldots \ldots \ldots \ldots \ldots$

Rice for Europeans and scrrants $\ldots \ldots \ldots \ldots \ldots \ldots$ \&

$\overline{35}$,

Rice and meal for porters $\ldots \ldots \ldots \ldots \ldots \ldots \ldots, 25$,

Total ........... 60,

In addition to his load, each portor carried, on learing the Sabi, $2 \frac{1}{2}$ days' rations of meal or rice for his own consumption.

About 25 loads of meal and rice had been sent forward to the Mahunjo 
(21 dnys' journey) 2 days before our depneture. Out of this the $2 \frac{1}{2}$ dars' rations coten on the vay there were replaced, uud the greater part of the remainder was left in chirgo of an Induna and a porter, as a reserve for us on the return journey.

We actually, therefore, started from the Mahunje with sobout $12 !$ day's' ratious for the porters.

On arrival at the Limpopo, by sending a party nearly a day's march into the Transvanl, we suceceded in purchnsiner five sacks of mealies. With this exception, the whole of the food consumed by the portens (cxcept a little meat and fish), on the marel from the Minhunjé to the Ihimpopo and back, a distance of 270 miles, was taken with us on starting from the Mnhunjé.

Tho following, which is likely to bo of interest as an example of what can be done with carricr tinusport, is a somewhat detailed account in cliary form of our march from the Sabi to the Inimpopo, and back to Massi-Késsi.

10th and 11th September.-Iseft carn! on the Sabi at 7.50 1.31., party consisting of five Europeans, two colourcel serrants, and 62 Indunas and porters. T'wo P'ortuguese member's of tho Commission accompanicd us as far as the Limpopo, but as their transport arrangements wore made independently of ours, they will not be further referred to.

Crossed the Luvdi about 4 miles after starting, and reached a large recly vley with good water, $1 \frac{1}{3}$ miles further on. Halted there duringr heat of day. Filled water-bottles, buckets, and calabashes. Started again at 3 1..3r., nud marched till dintk ( $S_{\frac{1}{2}}$ miles). No water. Dined and rested till 11 r.M., aul then continued tho march, with small halts, till 5 a.s. (133 miles), when we reached a deserted villnge with two small pools of stinking water. Slept till 7.30 A.31., then continned $60_{4}^{3}$ miles to a vley of good water, arriving there at 10 A.3r., having accomplished 34 miles in the preceding 26 hours. The porters vere so tired that it was determined to remain there for the rest of the dins.

12th September--Started at damn, and after 12 miles renched the ITahunjé, a dry rircr becl, in which watcr was obtainable by digging in the snnd. Found the bags of rice there which had been sent on from tho Sabi two days beforo om depirture. Issued 23 days' rntions to the porters to replace those that had alreads been consumed. Left an Induna and one natire in charece of a rescrese of 10 bags of rice, and set out on our narch across the totally unknown and unexplored district between the Jifahanjé and the Linpopo. Procecded 5 of piles in the afternoon. Water in pools in the river bed. Total for the day, $17 \frac{\pi}{4}$ miles.

13th September.-MIarched 17 miles in tho morning before we at length found some water in a reedy vley. Passed some deserted kraals on tho way. Continued $1 \frac{3}{4}$ miles in the afternoon. Water in pools in tho bed of the Babgwadzi rircr. Total for day, $18 \frac{3}{4}$ miles.

14th September-After $11 \frac{1}{2}$ miles, reached the Chefu IRiver. Bed itry, but water obtainable by digging in the sand. Found a fow natives living nen' tho river, but they lind no grain or meal, and were living 
a miserable existence on wild fruits and a small quantity of game. Continued 6 miles in the afternoon through thick bush and sand. No water at camp. T'otal for day, 17 miles.

15th September:-31 miles brought us to the Sectoala River. Dirtylooking water olitainable by digging in the river bed. Marched S. miles more to tho Guluzo river. Water obtainable by digging.; slightly ferruginons taste. Krals deserted. I'otal for day, 12 miles. We did not mnke any march in the afternoon, heiring that thero was no water for a considerablo distance.

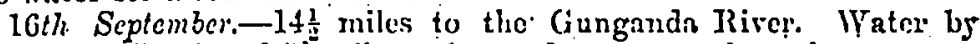
digging. Continued $5 \frac{1}{2}$ miles. Cimped at a spot where there was no water.' l'otal for day, 20 miles. Guides most unreliable and appear to have no idea of distance. Some say it will take.us. I $\frac{1}{2}$ days to our objective point on the Limpopo, qthers that we shall not be there for four dass. Great difficulty in arrainging our matrches: Sometimes, when tho guides tell us water is near at hand, it iproves to be many miles off, and at others, when they say it is far off; it turns ont to be comparatively close at hancl.

17th Septemler:- l21. miles to Mbatane's , kraal. Water from "holes." No fool supplies obtainable. 9 miles beyoul this we reached the Nuanetsi lirer, a broad dry rirer bed. Good water by digging. 'Total for day, $21 \frac{1}{2}$ miles.

$18 t h$ Sepicmber:-So tired that wo did not start until 6.15. A.3. Road through bush and sand. $8 \frac{1}{2}$ miles brought us to the Iimpopo, a broad running rivel. Ararched $6 \frac{1}{2}$ miles up the river iu the after: noon. 'Total for day, 15 miles. $\Lambda$ few fowls and eggs obtrinable at kraals, but no meal or rice.

$19 t h$ september.-Continued the march up tho Limpopo, aud crossed to the right bank at a point just above its junction with the Unvubu, $11+$ miles.: The natives here, as elserrhere, were liying on wild fruits, and anything else they could get. Sent five porters under the-Induna on to a place in the Transyaal, where it was reported some mealies were obtainable.

20th Scptember.-Day of rest. 'The porters returned in the erening, bringing fire loads of meal and mealies; all they had been gable to obtain.

At the Limpopo we sepanted from, the Portuguese oflicers who had accompanicd us so far. They proceeded direct to Delagon Bay, while pe returned to Jinssi-Kessi.

21st Septemler.-Commenced tho retarn march, proceeding by a shorter and more direct route to the Sabi. Camped on the bank of the Nuanetsi River. Water in pools in the rirer bed. 'lotal for day, lit miles.

22nd September:-No water till we reached the village of Iuatlatla, which had a well with n fair suppls, $16 \frac{3}{4}$ miles:

23rd Septernber.- Water $2 \frac{1}{4}$ miles after starting, and a small rles 14 miles beyond this. : Continued 3 ! miles beyond vioy. . No vater at camp. 'Total for dar, $199_{1}^{3}$ miles.

2.th September. $-6 \frac{1}{4}$ miles to the Bandaré River, in whịch we found some small prols of water. 53 miles beyond this, small rley of rery. 
muddy water. Camped at a spot without water. Total for dayr $17 \frac{1}{4}$ miles. Enropean servant ill; had to be carried in an extemporized masheela.

25th September.- $+\frac{1}{2}$ miles to the Chefn Rirer. Small pool of fairly good water. 15 miles more to the Babgwadze Rirer. Pools of water. Servant still ill and unable to walk. Total for day, 191 miles.

$20 t h$ September.-10 miles brought us back to the Mraliunje, wherc wo found the Indnna and porter we had left in charge of the reserve rice, and four other porters whom we had sent back lame two days after leaving there. Started again in the afternoon, taking all stores with us. Servant still had to be carried. Marched $9 \frac{1}{4}$ miles. No water at camp. Total for day, 20 miles.

27 th September.- Marched 23 miles to rles, where we filled ap all water-bottles, calabashes, buckets, de., and then continued 6 iniles to Intonjwasimba's. Kraal still deserted. Ono of the pools was quito dry, tho other still contained a small quantity of madd 5 stinking water. Marched 83 miles in afternoon. No water at carnp. Total for das, 181 miles.

28th September.-No water till we reached the large vley near the Lundi River-13! wiles. Reached depot on the Sabi River in the evening. Found Corpornl Whittle, B.S.A. Co.'s Police, and Isance. corporal Wilkins, R.E., in clarge of stores of food both for Europeans and natives of my party. 'Total for day, 183 miles. The journey to the Limpopo and back, $315 \frac{1}{2}$ miles, had taken 19 dajs, including $1 \frac{1}{2}$ days' rest on the Limpopo.

29th Septemer. -Day of rest.

30 th Septemler.-Started again in the morning, taking on crery one and all stores. Jetween the Sabi and Massi-Kessi, strearns of good water were always met with nt short intervals. No farther reference to water supply will, therefore, be mado in this diary. Camped at Garajwa's krual. Total for day, $38 \frac{1}{2}$ miles.

1 st October.-Reached the Alongesi River-16 miles. Fine rain fell ciuring the morning.

2nd October.-At Mnsigoboja's kmal (9t miles) fond an Indons. and two of our porters in charge of 15 loads of meal, which had been collected by Captain Lawrence, and left thero for us. Continued in the afternoon to the camp on the Nyangamba, at which Captain Turner had died and been buried daring our absence. Total for day, $144_{4}^{3}$ miles.

3rd October.-Fine rain fell in the afternoon and crening. JIarched by a new route $14 \frac{3}{4}$ miles.

4th October.-Heavy mist during greater part of day. Corporal Johnson down with fever and bilious attack; had to be carried. Harched 14t miles. Camped on the Umswilisi River.

5th October.-Continued tho march and crossed tho Busi river. Total for day, 173 miles.

6th Oclober.-Corporal Johuson still ill and had to be carrich.

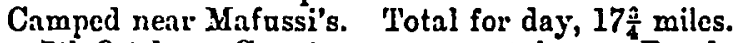

7th Octobcr.-Country very, mountainons. Reached the Lusitu Riverin the afternoon (16 miles), where we found Trooper Jones, of tho 
B.S.A. Co.'s Police, and a coloured servant in charge of a qaantity of stores, left for us by Captain Lawrence.

8th October.-Day of rest. Corporal Whittlo taken violently ill in the early morning-dysentery and fercr. Showery during day, rain at night.

9th October.-Corporal Whittle too ill to be moved. Scnt off nativ: messengers for Dr. Hayner, who was with Captain Lawrence, and was beliered to be encamped somewhere near Chimanimani.

It being imperative that I should reach Massi-Kessi as soon as possible, it was decided that Captrin Grant, Corporal Wilkins, and 'rooper Jones should remain on tho Lusitu to look after Corporal Whittle, whilo I continued the march, accompanied by Mr. Sarille, Corporal Jolnson, my whito scrvant, and 34 porters.

Started in the afternoon, and found that the Lusitu had risen very considerably, being $3 \mathrm{ft}$. deep at tho drift. After crossing the river, there is a very steep ascent of over 2,000 ft. 'Total for day, 60! miles.

10th October.-Very hears mist in carly morning. Marched 18 $\frac{1}{2}$ miles.

1lth October.-Crossed tho Chimanimani Pass, 5,150 fect, and mot Dr. Rayner on the other side of it. He had received my message, and was on his way back to the Lasitu. Tho attack of ferer from which Corporal Whittle was suffering proved to be a very serions one, but he eventaally pulled through. Reached Malanda's kraal (10! miles) in afternoon. IIears storm of thander and rain before we reached therc. Found Captain Lawrence therc, and also a depôt of stores in chargo of two of the B.S.A. Co.'s Police.

Lieutenant Wilson and Corporal Davis, R.W., were away surreying along the watershed between the basins of the Bnsi and tho Sabi.

12th October.-Stcady downponr all day. Remained in camp.

13th October.-Rained till 10 A.M. Very misty. Started at 1 1.s. Captain Lawrence accompansing us. Camped on the Manwingi River, 11 miles. Rain at night.

$14 t h$ October. - Some showers. Marched $22 \frac{3}{4}$ miles.

15 th October.-Reached Mrassi-Kessi at 5.30 P.M._-21 miles.

The distances marched, from our departure from the Sabi on the10th September to oar arriral at Massi-Kessi on the 15th October, were-fron the Sabi to the Limpopo, 168 $\frac{1}{4}$ miles; from the Limpope to Massi-Kessi, 376 miles; total, $544 \frac{1}{4}$ milcs. Tho time occupied was 36 dajs, but this included $1 \frac{1}{2}$ days' rest on the Iimpopo, 1 day ors the Sabi, and $1 \frac{1}{2}$ days on tho Lnsitn, and $1 \frac{1}{2}$ days'defention by rain at Malanda's, thus reducing the marching dags to $30_{2}^{1}$. The areragc distance marched each day for the whole 36 days was, therefore, $15 \cdot 12$ miles, and for cach marching day $17 \cdot 8.1$ miles.

Throughout the whole march, both Europeans and natives wero on foot, and native porters were the only means of transport for our supplies, baggage, \&c. There were no roads but tortuons Kaffir paths; part of the country traversed was bush and sand, while other portions were very mountainous, and the whole of it was sitnated within the tropics. More than 250 miles of our ronte were quite 
untrivelled, and wo lad been .able to obtain only tho scantiest information about tliis portion of it heforehand. 17 to 18 miles a-day may not secm much to persons only aceustomed to the well-made roads of civilized countries, but, owing to the great heat. and the badness of the tracks, this was as much is either Furopeans or porters could manage, and on arrival at canp in the evening ereryone was thoroughly tired out.

Hy the 23rd October creryone had been withdrawn from the country south of Massi-Kessi.

On the following day the greater part of the Comnission started in a northerly direction, and procecded through an crcessively monntainous district to: the main watershed between the basins of the Pungwe and the Zambesi: Ou' -movements were nuch impeded byrain, and the mountain tops were so constantly corcred with mist that surrey. operations were only carricd on with cxtreme difliculty.

I got back to Massi-Kessi on the llth November, haring made a détorr in order to visit Umtasa's kraal, and found that Captain Grant and-Scrgeant Clarke, who had separated from us: n:fers days after learing Mrassi-Kessi in order to complete some surver work, hand alrealy arrived.:

On the following day (12th Norember) Lieutenant W.ilson, Ird Rayner, and DIr: Savillo reached Mrassi-Kessi direct from the Zambesi: Pungwé .watershed, where. I. Lad left them owing to Mr. Saville being rlaigl: up with a very. serious attack of forer. 'They had been delayed on..the banks of the I'ungive, which had risen in consequenco of. the rains, and lind land to wait to cross it till the viaters liad subsided.

On the 14th November- Captain Lanrence left Massi-Kessi with about - half the British 'section; of the Commission, aud on the following day. I followed with Captain Grant and the remainder. . We reached. Mapanda's on the $23 \mathrm{ld}$, corcring tho 157 miles between - it and Massi-Kessi in $8 \frac{1}{1}$ days, or an arerago of 18.47 .miles per day. 'There was a good deal of rain during this period, ibut. as it fell generally at night it did not interfore very. much with our. purogress.

From Mapanda's we went down the river by boat-to Fontesvilla, which had sprung into existeuce during our.absence, and is the starting point of the railway now. in courso of constraction to Shimosa's; and proceeded from there by steamer to Beirn.

The detachment of 'the British South Africa .Company's: police attached to tho Comnsission bronght their own supplics: with them from Umtali. '. The whole of the food, except fresl meat, required for the rest of the 'Europeans, belonging to the British': section of the Commission was taken :out. from Fngland, and wats, calculated to be sufficient tò last 12 persons for.bet ween 8 and 9 monthse.

Everything was supplied by the Army: aud Nary Co:operative Society, packed in cases suituble for carrier, trausport; yand the Commission is much indebted to Major MIcCrea, the nanaging director, for the great:trouble which he personally took in the imatter.

For simplification and conrenience of issue the various, articles of food were grouped in fonr categories, riz.; groceries, breadstuffs, :meat, 
Inxaries. When a party was ordered away there was no weighing and measuring out of rations. 'The officer in command had merely' to demand one or more cases of each catergors according to the strength of the party and the time it was likely to bo absent.

The following details concerning the cases and their contents may; possibly be of use to persons fitting out expeditions similar to the one on which we wern engaged :-

\section{Groceries-}

70 cases, cach containing-

'Tea, 2 lbs. in $\frac{1}{2}-l b$. soldered tins.

Coffec, 2 lbs. in 1-lb. soldered tins.

Cocon, Van Houten's, 1 lb. in $\frac{1}{4}$-lb. tins.

Loaf sugar, 4 lbs. in a soldered tin.

Salt, $1 \mathrm{lb}$.

Pepper, $\frac{1}{t}$ ll.

Lard, $1 \mathrm{lb}$. in a soldered tin.

Arrowloot, $\frac{2}{2} \mathrm{lb}$. in a soldered tin.

Brand's essence of beef, two 4-07. tins.

Condensed milk, 2 tins.

Solidificd soups, 12 squares in a soldered tin.

Marmalade, four 1-lb. tins.

Curry powder, two $\frac{1}{4}-1 b$. tins.

Potted meats, four $\frac{1}{4}-1 \mathrm{l}$. tins.

Baking powder, one $\frac{1}{1}-1 \mathrm{l}$. tin.

Carbolic soap, 3 pieces

Bromo paper, I packet $\}$ packed in watcrproof paper.

Ozokerit candles, 3 lbs.

Compressed regetables, $2.1 \mathrm{lbs}$. in a soldered tin.

Tin-opening knires, 2.

Dubbiti, 1 tin.

The. size of the cases was $28 \frac{1}{2}$ in. long by, 13 in: broad, and 8 .in. deep. Each weighed, when full, exactl 50 Ibs. Ten of them were secured by locks and keys, and woro used as cxpeuse stores. The lids of the remainder, for the sake of economy, were only scieved down. Whenever it became necessary to open one of the latter its contents were at onco transferred to one of thoso with lock and key, which had already been emptied.

The arrowroot and essence of beef werc looked upon as nedical comforts, and were reserved for tho use of the sick.

Each case was supposed to contain about 42 rations. The tea and coffee were rather more than actually required, bit. the excess came in handy for issue to tho coloured serrants (Indians and.Cape bojs). The sugar ration ( $l \frac{1}{2}$.oz.) was rather small, but the weight of tho cases having to bo kept down, it was fonud inexpedient to put more than 4 lbs. in each. The ration was, howerer, usually, increased by the issue of sone brown sugar, threo loads of which were bouglit after our arrival in South Africa. The quantities of preserved milk and marmalade were also small, but these were iot reckoned as 
absolute necessaries, and except on special occasions when the transport had to be reduced to a minimum could always be supplemented from the luxury boxes.

Breadstufjs.-4.4 cases, each containing $40 \mathrm{lbs}$. flour in 4 soldered tins of 10 lbs. cach. The size of tho cases was $22 \frac{1}{2}$ in. $x 18$.in. $\times 91$ in., and their weight when full alout 55 los.

63 cases of best cabin biscuits, each case containing 2 tins of $14 \mathrm{lbs}$. cacl. The size of the cases was $21 \frac{1}{2}$ in. $\times 15$ in. $\times 13$ in., and their weight when full about 46 lbs.

Tho normal daily ration was $1 \mathrm{lb}$. flour, or $1 \mathrm{lb}$. biscuit. It was found, however, in practice that while the full ration of biscuit was rircly consumed, $1 \mathrm{lb}$. of Aour provided rather short commons, and towards the cud of the expedition the flour ration was raised to $1 \frac{1}{4}$ lbs.

It is of the utmost necessity that all tins should bo securely soldered as a protection agninst wet and damp. Tho tins for tho flour were specially mado for us by tho Army and Nary Co-operatiro Society, and answered their purpose admirably, but the biscuits wero in the original tins supplied by the biscuit manufacturers, and in some few instances got damaged by wet, and became mouldy and uneatable owing to the soldering having giren way in places. Our experience teaches that it would be a wise precaution to bare all tins, not specially made for the expedition on which they are to be taken, carefully examined and resoldered, if necessary, before being packed.

Meat.-51 cases each containing 32 lbs. preserved meat in 16-2-lb. tins. The size of the cases was $19 \frac{1}{2}$ in. $\times 11$ in. $\times 10 \frac{1}{2}$ in., their weight when full about 50 lbs.

Tho ment was of rarious kinds. That which was liked best was the roast beef. The daily ration when issued was $1 \mathrm{lb}$. for ench person.

The total amount taken with us was only calculnted for rather more than half the period the expedition ras expected to last. For the rest of the time wo counted on getting fresh meat or game.

Luxurics.-32 cases containing prescived fish and regctables, sansages, sardines, butter, condensed milk, jams, mustard, de.

These articles did not form part of the regular ration, but wero issued in small quantities as extras. Those which were most appreciated wero the jams and milk, and daring the cold weather tho batter, but tins of the last mentioned were found to be quite liquid if opencd during the hot season, and could not bo used except for cooking purposes.

The supplies taken with us included also 3-4-gallon kegs of limejuico weigling about 56 lbs. each. On tho days when issued the ration was $1 / 2$.tth of an ordinary quart bottle for ench person.

.T'ca, coffec, or cocoa were drunk at all meals. A ration of whisky or brandy consisting of $1 / 12$ th of a bottle was, however, serred out before going to bed every second night during part of the expedition, and every night at other times. We took no wine or beer with us except a small quantity of champagne iutended for use in case of sickncss. 
In the way of dress and camp equipment, except tents which were provided at Government expense, the officers attached to the Commission were allowed to provide pretty well what they liked, tho onls limitations being as regards quantity and suitability for carrier transport.

The ontfit of the fire non-commissioned officers of Rojal Engineers was specially prepared at tho Axmy Clothing Depôt, Pimlico. As it proved most serviceable and satisfactory, and mas possibly scrre as $\Omega$ useful guide in the future, a detailed acconnt of it is giren below.

The articles issued to each man were as follows, riz. :-

\title{
Sea Kit-
}

\author{
1 blue serge frock. \\ I pair blue seige tronsars. \\ 1 worsted cap. \\ 6 pieces soap. \\ 1 clothes-bag. \\ 1 houserife.
}

\section{Spccial Kit-}

2 brown serge Khake frocks with four front pockets.

2 pairs Bedford cord knickerbncker brecches.

2 pairs brown canras leggings (Abjssinian pattern).

1 whito waterproof tropical cont.

1 bluo woollen jersey.

2 whito fannel pyjama sleeping suits.

3 flannel cholera belts.

1 white havresack.

1 waterproof caralry kit-bag.

2 infintry mess tins.

4 pairs cotton drawers.

4 blue-grey flannel shirts.

2 white tropical shirts.

4 pairs worsted socks.

1 white helmet (10th Hussars pattern).

1 puggaree.

3 pairs forcign serrice ankle-boots.

The cost of the abore (sea-kit and special kit), including badges of rank and ornaments, amounted to an arerago of $10 \mathrm{l}$. 8 s. per man.

In addition to the articles abore enumerated, cach man took with him 1 pair regimental trousers, 1 red frock, I great coat, 1 forage cap, and such underclothing and boots as he happened to be. in possession of.

In the way of equipment cach man was supplied with 2 ordinary soldier's water-bottles ( 1 for use and 1 in reserve) 2 blankets, 1 waterproof ground shect, 1 pocket filter, brown leather belt and pouches, a Martini-Henry Artillery carbine, and a Webley rerolrer, the last 
mentioncl for use when surveging, and the carbine could not be carried.

The tents ased by the Commission were supplied by Benjamin Fdgington, Limited, and were made of green rot-proof canras, which prored to be most durable, and rely imperrious to rain.

The pattern found most convenient was the so-called "Suakin" tent, a double roof rilge-tent $6 \mathrm{ft} .9 \mathrm{in}$. square at base, $6 \mathrm{ft} .6 \mathrm{in}$. high in the centre, and $2 \mathrm{ft}$. 6 in. at the sides, with an outer roof orfly projecting all round, and jointed lard-wood poles and ridge piece. This tent complete with mallets, pegs. and bags formed two convenient sized londs of about $10 \mathrm{lbs}$. ench when diy.

Fnll details regarding the instruments and other special equipment taken out for the survey work of the commission hare alreadybeen published in an article by Captain Grant, in vol. xix (1893) of the Professional Papers of the Corps of Rogal Engineers. 


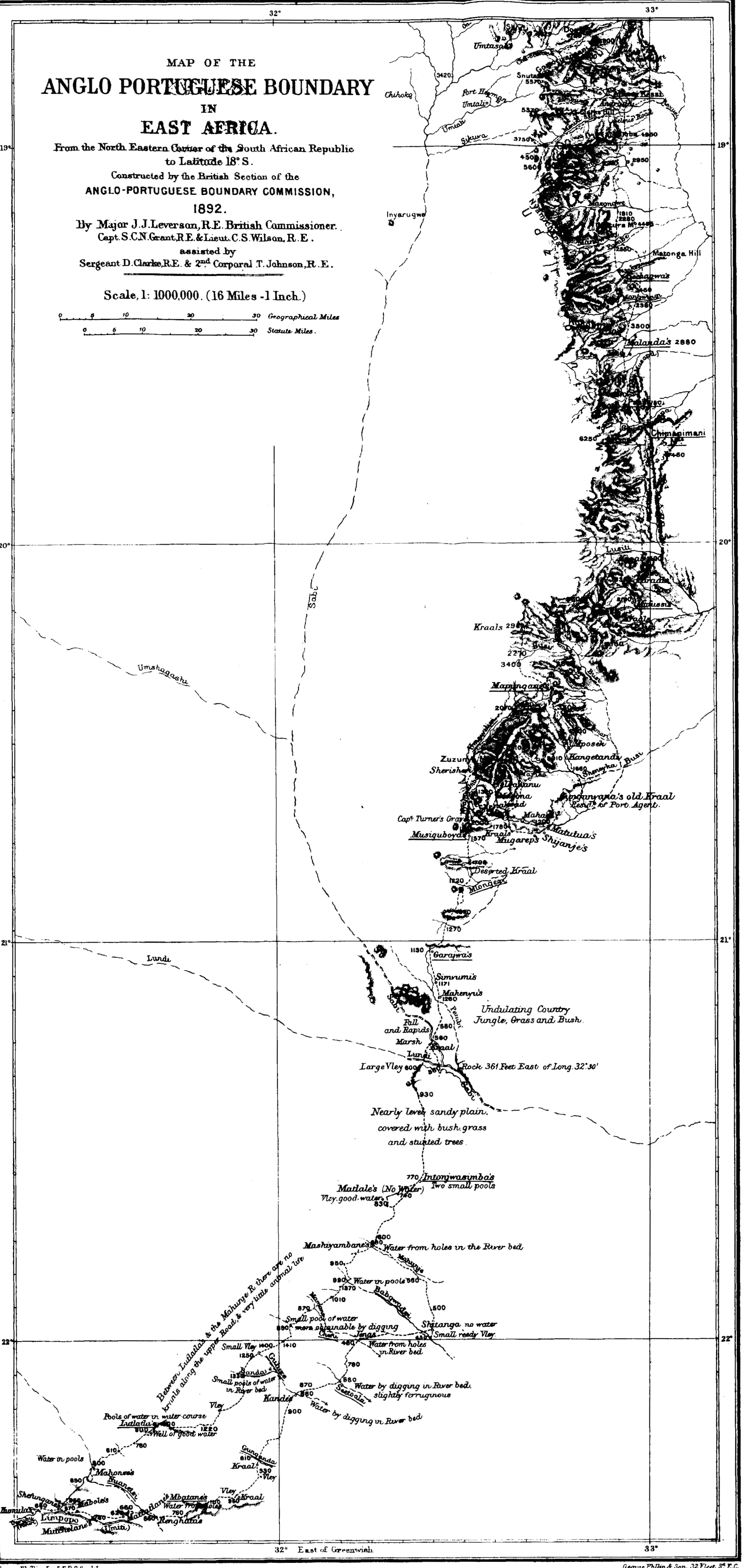

